\title{
Synthesis, DNA Binding, Topoisomerase Inhibition and Cytotoxic Properties of 2-Chloroethylnitrosourea Derivatives of Hoechst 33258
}

\author{
Krzysztof Bielawski, ${ }^{*}, a$ Anna Bielawska, ${ }^{a}$ Tomasz Anchim, ${ }^{b}$ and Sławomir WolczyŃski ${ }^{b}$ \\ ${ }^{a}$ Department of Medicinal Chemistry and Drug Technology, Medical University of Biakystok; Mickiewicza 2, 15-089 \\ Białystok, Poland: and ${ }^{b}$ Department of Gynecological Endocrinology, Medical University of Białystok; Sktodowskiej 24A, \\ 15-276 Bialystok, Poland. Received December 6, 2004; accepted February 21, 2005
}

A number of novel 2-chloroethylnitrosourea derivatives of Hoechst 33258 were synthesized and examined for cytotoxicity in breast cancer cell cultures and for inhibition of topoisomerases I and II. Evaluation of the cytotoxicity of these compounds employing a MTT assay and inhibition of $\left[{ }^{3} \mathrm{H}\right]$ thymidine incorporation into DNA in both MDA-MB-231 and MCF-7 breast cancer cells demonstrated that these compounds were more active than Hoechst 33258. The DNA-binding ability of these compounds was evaluated by an ultrafiltration method using calf thymus DNA, poly(dA-dT $)_{2}$ and poly(dG-dC $)_{2}$, indicated that these compounds as well as Hoechst 33258 well interact with AT base pair compared with GC pair. Binding studies indicate that these compounds bind more tightly to double-stranded DNA than the parent compound Hoechst 33258. The degree to which these compounds inhibited cell growth breast cancer cells was generally consistent with their relative DNA binding affinity. Mechanistic studies revealed that these compounds act as topoisomerase I (topo I) or topoisomerase II (topo II) inhibitors in plasmid relaxation assays.

Key words cytotoxicity; Hoechst 33258; chloroethylnitrosourea; DNA-binding; ultrafiltration assay; DNA topoisomerase

Several chloroethylnitrosoureas were developed and proved effective against both solid and intracranially implanted tumours in animals. ${ }^{1)}$ From further studies, several drugs were introduced clinically, including $N, N^{\prime}$-bis(2chloroethyl)- $N$-nitrosourea (carmustine), $N$-(2-chloroethyl)$N^{\prime}$-cyclohexyl- $N$-nitrosourea (lomustine), and $N$-(2-chloroethyl)- $N^{\prime}$-(diethyl)ethylphosphonate- $N$-nitrosourea (fotemustine). ${ }^{2,3)}$ Exposure to chloroethylnitrosoureas leads to the formation of crosslinks between guanine and cytosine residues on opposite strands of DNA. ${ }^{3)}$ However, most of chloroethylnitrosoureas have only a limited degree of sequence specificity, which implies that they may hit all the cellular genes. DNA minor groove binders represent a class of cytotoxic agents whose DNA sequence specificity may lead to a high selectivity of action. ${ }^{4,5)}$ Targeting reactive moieties to DNA by attachment of a DNA minor groove binding carrier such as distamycin or Hoechst 33258 reduces the loss of active drug due to reaction with other cell components and makes it possible to direct the alkylation both sequence specifically and regiospecifically. ${ }^{6-8)}$ Hoechst 33258 (Fig. 1) is a headto-tail bis-benzimidazole compound that specifically recognises three consecutive AT base pairs in the minor groove of B-form DNA. ${ }^{9,10)}$ It has been the starting point for a number of recent drug design studies aimed at developing analogues with, in particular, anticancer activity. ${ }^{6,11-14)}$ In our previous papers we reported the synthesis and structure-activity studies of carbamate derivatives of Hoechst 33258, which appeared to be a new class of cytotoxic minor groove binders. ${ }^{14)}$ The promising biological data obtained with these compounds have encouraged the synthesis of a novel series of Hoechst 33258 derivatives bearing a chloroethylnitrosourea moiety (Fig. 1).

In this study, we have investigated the antiproliferative activity of these bis-benzimidazole derivatives 3-5 (Fig. 1) in both MDA-MB-231 and MCF-7 breast cancer cells and assessed their ability to act as inhibitors of topoisomerases I and II (topo I and II). The DNA-binding ability of these compounds were studied employing the ultrafiltration method using calf thymus DNA, poly $(\mathrm{dA}-\mathrm{dT})_{2}$ and poly $(\mathrm{dG}-\mathrm{dC})_{2} \cdot{ }^{14-17)}$

\section{CHEMISTRY}

Melting points were determined on Buchi 535 meltingpoint apparatus and were uncorrected. Analyses were performed on a Perkin Elmer 2400 analyser. ${ }^{1} \mathrm{H}-\mathrm{NMR}$ (200 $\mathrm{MHz})$ and ${ }^{13} \mathrm{C}-\mathrm{NMR}(150 \mathrm{MHz})$ spectra were recorded on a Bruker AC 200F spectrometer, using TMS as an internal standard. Hoechst 33258, glicyne, L-alanine, L-valine, DMF,

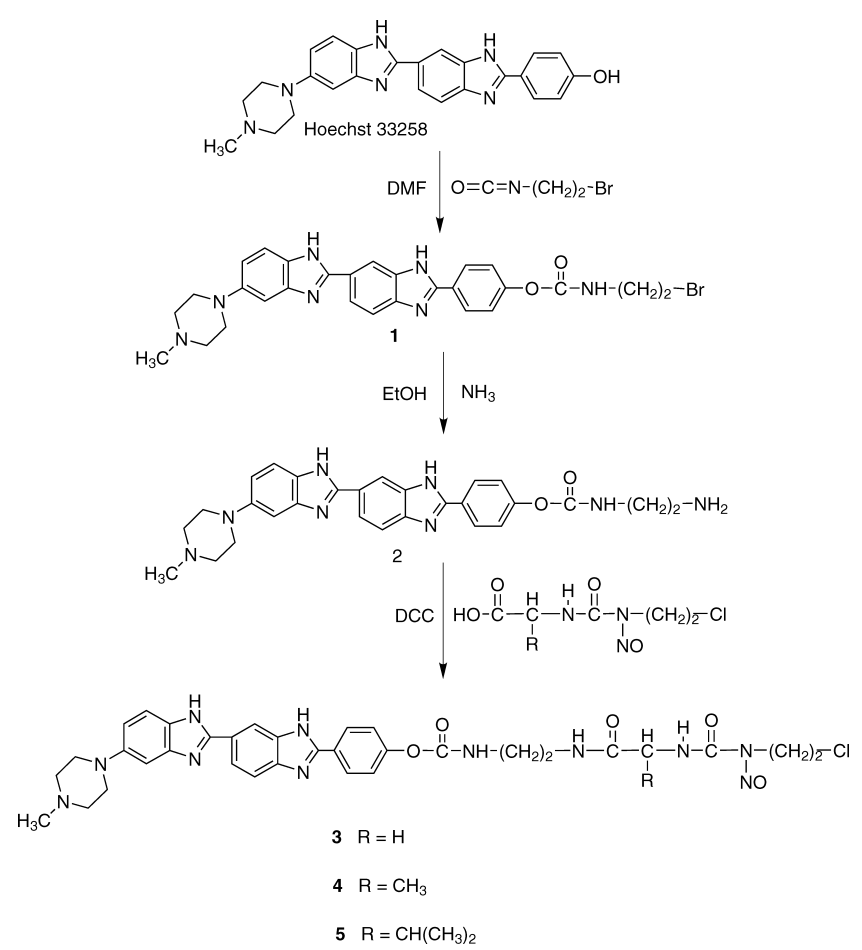

Fig. 1. Synthesis of Compounds $\mathbf{1}-\mathbf{5}$ 
triethylamine, $N, N^{\prime}$-dicyclohexylcarbodiimide, 2-chloroethyl isocyanate, and 2-bromoethyl isocyanate, were purchased from Sigma (U.S.A.). The compound 1 (Fig. 1) and $N-[N-(2-$ chloroethyl)- $N$-nitrosocarbamoyl]amino acids were synthesized as reported in the literature. ${ }^{14,17,18)}$

Synthesis of 2-[2-(4-((2-Aminoethyl)carbamoyloxy)phenyl)-6-benzimidazolyl]-6-(1-methyl-4-piperazinyl)benzimidazole Tetrahydrochloride (2) The compound 1 ( $2 \mathrm{mmol})$ was dissolved in $15 \mathrm{ml}$ absolute ethanol and the mixture was cooled to $0{ }^{\circ} \mathrm{C}$. Anhydrous ammonia was slowly bubbled into the reaction mixture for $1 \mathrm{~h}$. The reaction mixture was stirred for $48 \mathrm{~h}$ at ambient temperature and concentrated under reduced pressure. The resulting oil was purified by column chromatography over $\mathrm{Al}_{2} \mathrm{O}_{3}$ (III grade) (1:1 $\mathrm{MeOH}$ : EtOAc solvent linearly changing to $100 \% \mathrm{MeOH})$. Conversion of the compound $\mathbf{2}$ into the hydrochloride salt was achieved with $2 \mathrm{~m}$ hydrogen chloride in methanol. The trihydrochloride salt of 2 was crystallized from $96 \%$ ethanol. Yield $=78 \%, \mathrm{mp}>300{ }^{\circ} \mathrm{C} .{ }^{1} \mathrm{H}-\mathrm{NMR}\left(\mathrm{DMSO}-d_{6}\right) \delta: 2.62(\mathrm{~s}$, $\left.3 \mathrm{H}, \mathrm{N}-\mathrm{CH}_{3}\right), 2.78\left(\mathrm{~m}, 4 \mathrm{H}, \mathrm{N}-\mathrm{CH}_{2}-\right), 2.92$ (t, $2 \mathrm{H}, \mathrm{CH}_{2}-\mathrm{NH}_{2}$, $J=5.8 \mathrm{~Hz}), 3.36\left(\mathrm{~m}, 4 \mathrm{H}, \mathrm{N}-\mathrm{CH}_{2}-\right), 3.46\left(\mathrm{t}, 2 \mathrm{H}, \mathrm{N}-\mathrm{CH}_{2}-\right.$, $J=5.8 \mathrm{~Hz}), 6.95$ (d, $1 \mathrm{H}, \operatorname{Ar}-\mathrm{H}, J=8.4 \mathrm{~Hz}), 7.11(\mathrm{~s}, 1 \mathrm{H}$, $\mathrm{Ar}-\mathrm{H}), 7.45(\mathrm{~d}, 1 \mathrm{H}, \mathrm{Ar}-\mathrm{H}, J=9.0 \mathrm{~Hz}), 7.71$ (d, 1H, Ar-H, $J=9.2 \mathrm{~Hz}), 7.82$ (d, 2H, Ar-H, $J=8.2 \mathrm{~Hz}), 8.04$ (d, $1 \mathrm{H}$, $\mathrm{Ar}-\mathrm{H}, J=8.7 \mathrm{~Hz}), 8.19(\mathrm{~d}, 2 \mathrm{H}, \mathrm{Ar}-\mathrm{H}, J=9.4 \mathrm{~Hz}), 8.40$ (s, $1 \mathrm{H}, \mathrm{Ar}-\mathrm{H}) .{ }^{13} \mathrm{C}-\mathrm{NMR}\left(\mathrm{DMSO}-d_{6}\right) \delta: 40.8\left(\mathrm{CH}_{2}-\mathrm{NH}_{2}\right), 41.4$ $\left(\mathrm{N}-\mathrm{CH}_{3}\right), 48.4\left(\mathrm{~N}-\mathrm{CH}_{2}-\right), 53.5\left(\mathrm{~N}-\mathrm{CH}_{2}-\right), 102.5$ (Ar), 116.7 (Ar), 117.0 (Ar), 123.2 (Ar), 126.4 (Ar), 128.2 (Ar), 130.5 (Ar), 130.9 (Ar), 132.3(Ar), 149.8 (Ar), 153.9 (Ar), 155.5 (Ar), 157.8 (OCO). Anal. Calcd for $\mathrm{C}_{28} \mathrm{H}_{30} \mathrm{ClN}_{8} \mathrm{O}_{2} \cdot 4 \mathrm{HCl}$. $3 \mathrm{H}_{2} \mathrm{O}: \mathrm{C}, 47.33 ; \mathrm{H}, 5.67 ; \mathrm{N}, 15.77 ; \mathrm{Cl}, 19.96$. Found: $\mathrm{C}$, $47.41 ; \mathrm{H}, 5.60 ; \mathrm{N}, 15.67 ; \mathrm{Cl}, 19.85$.

General Method of Synthesis for 3 to 5 Compound 2 ( $1 \mathrm{mmol}$ ) was dissolved in $10 \mathrm{ml}$ of anhydrous DMF. To this stirring solution triethylamine $(1 \mathrm{mmol})$ was added. The solution was cooled to $0^{\circ} \mathrm{C}$ before adding $N$-[N-(2-chloroethyl)$N$-nitrosocarbamoyl]amino acid $(1 \mathrm{mmol}){ }^{18,19)}$ This provided a clear solution into which $N, N^{\prime}$-dicyclohexylcarbodiimide ( $1 \mathrm{mmol}$ ) was added all at once. It was stirred at $0{ }^{\circ} \mathrm{C}$ for $5 \mathrm{~h}$, and then warmed to room temperature where it was kept for $24 \mathrm{~h}$. The precipitate of dicyclohexylurea was removed by filtration. The powder obtained on solvent removal was further purifed by preparative TLC (silica gel plates, $1: 1 \mathrm{MeOH}$ : $\mathrm{EtOH})$ to give the product as a yellow powder. The free base was converted into the salt by taking up in $2 \mathrm{M}$ hydrogen chloride in methanol. Acetone was added and the final product was filtered, washed with acetone and crystallized from methanol.

4-(6-(5-(4-Methylpiperazin-1-yl)-benzimidazol-2-yl)benzimidazol-2-yl)phenyl 2-(2-(3-(2-Chloroethyl)-3-nitrosoureido)acetamido)ethylcarbamate Trihydrochloride (3): Yield $=44 \%, \mathrm{mp}>300{ }^{\circ} \mathrm{C} .{ }^{1} \mathrm{H}-\mathrm{NMR}\left(\mathrm{DMSO}-d_{6}\right) \delta: 2.65(\mathrm{~s}, 3 \mathrm{H}$, $\left.\mathrm{N}-\mathrm{CH}_{3}\right), 2.80\left(\mathrm{~m}, 4 \mathrm{H}, \mathrm{N}-\mathrm{CH}_{2}-\right), 3.24\left(\mathrm{t}, 2 \mathrm{H}, \mathrm{N}-\mathrm{CH}_{2}-\right.$, $J=6.2 \mathrm{~Hz}), 3.38\left(\mathrm{~m}, 4 \mathrm{H}, \mathrm{N}-\mathrm{CH}_{2}-\right), 3.46\left(\mathrm{t}, 2 \mathrm{H}, \mathrm{N}-\mathrm{CH}_{2}-\right.$, $J=6.2 \mathrm{~Hz}), 3.55\left(\mathrm{t}, 2 \mathrm{H},-\mathrm{CH}_{2}-\mathrm{Cl}, J=6.2 \mathrm{~Hz}\right), 4.05(\mathrm{~s}, 2 \mathrm{H}$, $\left.\mathrm{CH}_{2}\right), 4.20\left(\mathrm{t}, 2 \mathrm{H}, \mathrm{N}-\mathrm{CH}_{2}-, J=6.2 \mathrm{~Hz}\right), 6.95(\mathrm{~d}, 1 \mathrm{H}, \mathrm{Ar}-\mathrm{H}$, $J=8.4 \mathrm{~Hz}), 7.05$ (s, 1H, Ar-H), 7.45 (d, 1H, Ar-H, $J=$ $9.0 \mathrm{~Hz}), 7.71(\mathrm{~d}, 1 \mathrm{H}, \mathrm{Ar}-\mathrm{H}, J=9.2 \mathrm{~Hz}), 7.82$ (d, 2H, Ar-H, $J=8.2 \mathrm{~Hz}), 8.04$ (d, 1H, Ar-H, $J=8.7 \mathrm{~Hz}), 8.19$ (d, 2H, $\mathrm{Ar}-\mathrm{H}, J=9.4 \mathrm{~Hz}), 8.38(\mathrm{~s}, 1 \mathrm{H}, \mathrm{Ar}-\mathrm{H}) .{ }^{13} \mathrm{C}-\mathrm{NMR}$ (DMSO- $\left.d_{6}\right)$ $\delta$ : $38.4\left(\mathrm{CH}_{2}-\mathrm{NH}\right), 41.4\left(\mathrm{~N}-\mathrm{CH}_{3}\right), 42.0\left(\mathrm{CH}_{2}-\mathrm{Cl}\right), 41.3$
$\left(\mathrm{N}-\mathrm{CH}_{2}-\right), 43.6\left(\mathrm{~N}-\mathrm{CH}_{2}\right), 46.2\left(\mathrm{CH}_{2}-\mathrm{N}\right), 53.5\left(\mathrm{~N}-\mathrm{CH}_{2}-\right)$, 102.5 (Ar), 116.7 (Ar), 116.9 (Ar), 123.2 (Ar), 126.4 (Ar), 128.2 (Ar), 130.5 (Ar), 130.9 (Ar), 132.2 (Ar), 149.8 (Ar), 153.9 (Ar), 153.3 (CO), 155.5 (Ar), 157.8 (OCO), 170.8 (CO). Anal. Calcd for for $\mathrm{C}_{33} \mathrm{H}_{36} \mathrm{ClN}_{11} \mathrm{O}_{5} \cdot 3 \mathrm{HCl} \cdot 2 \mathrm{H}_{2} \mathrm{O}: \mathrm{C}$, 46.76; H, 5.11; N, 18.18; Cl, 16.73. Found: C, 46.71; H, 5.05; N, 18.07; Cl, 16.70.

4-(6-(5-(4-Methylpiperazin-1-yl)-benzimidazol-2-yl)benzimidazol-2-yl)phenyl 2-(2-(3-(2-Chloroethyl)-3nitrosoureido)propanamido)ethylcarbamate Trihydrochloride (4): Yield $=32 \%, \mathrm{mp}>300{ }^{\circ} \mathrm{C}$. ${ }^{1} \mathrm{H}-\mathrm{NMR}\left(\mathrm{DMSO}-d_{6}\right) \delta$ : $1.54\left(\mathrm{~d}, 3 \mathrm{H}, \mathrm{CH}_{3}-, J=7.5 \mathrm{~Hz}\right), 2.65\left(\mathrm{~s}, 3 \mathrm{H}, \mathrm{N}-\mathrm{CH}_{3}\right), 2.80(\mathrm{~m}$, $4 \mathrm{H}, \mathrm{N}-\mathrm{CH}_{2}-$ ) , 3.24 (t, $\left.2 \mathrm{H}, \mathrm{N}-\mathrm{CH}_{2}-, J=6.2 \mathrm{~Hz}\right), 3.38$ (m, 4H, $\left.\mathrm{N}-\mathrm{CH}_{2}-\right), 3.46\left(\mathrm{t}, 2 \mathrm{H}, \mathrm{N}-\mathrm{CH}_{2}-, J=6.2 \mathrm{~Hz}\right), 3.55(\mathrm{t}, 2 \mathrm{H}$, $\left.-\mathrm{CH}_{2}-\mathrm{Cl}, J=6.2 \mathrm{~Hz}\right), 4.20\left(\mathrm{t}, 2 \mathrm{H}, \mathrm{N}-\mathrm{CH}_{2}-, J=6.2 \mathrm{~Hz}\right), 4.65$ (q, $1 \mathrm{H}, \mathrm{CH}, J=7.5), 6.95$ (d, $1 \mathrm{H}, \mathrm{Ar}-\mathrm{H}, J=8.4 \mathrm{~Hz}), 7.05$ (s, $1 \mathrm{H}, \mathrm{Ar}-\mathrm{H}), 7.45(\mathrm{~d}, 1 \mathrm{H}, \mathrm{Ar}-\mathrm{H}, J=9.0 \mathrm{~Hz}), 7.71(\mathrm{~d}, 1 \mathrm{H}$, $\mathrm{Ar}-\mathrm{H}, J=9.2 \mathrm{~Hz}$ ), 7.82 (d, 2H, Ar-H, $J=8.2 \mathrm{~Hz}), 8.04$ (d, $1 \mathrm{H}, \mathrm{Ar}-\mathrm{H}, J=8.7 \mathrm{~Hz}$ ), 8.19 (d, 2H, Ar-H, $J=9.4 \mathrm{~Hz}), 8.38$ $(\mathrm{s}, 1 \mathrm{H}, \mathrm{Ar}-\mathrm{H}) .{ }^{13} \mathrm{C}-\mathrm{NMR}$ (DMSO- $\left.d_{6}\right) \delta: 18.0\left(\mathrm{CH}_{3}\right), 38.4$ $\left(\mathrm{CH}_{2}-\mathrm{NH}\right), 41.4\left(\mathrm{~N}-\mathrm{CH}_{3}\right), 42.0\left(\mathrm{CH}_{2}-\mathrm{Cl}\right), 41.3\left(\mathrm{~N}-\mathrm{CH}_{2}-\right)$, $43.6\left(\mathrm{~N}-\mathrm{CH}_{2}\right), 52.0(\mathrm{CH}-\mathrm{N}), 53.5\left(\mathrm{~N}-\mathrm{CH}_{2}-\right), 102.5(\mathrm{Ar})$, 116.7 (Ar), 116.9 (Ar), 123.2 (Ar), 126.4 (Ar), 128.2 (Ar), 130.5 (Ar), 130.9 (Ar), 132.2 (Ar), 149.8 (Ar), 153.9 (Ar), 153.3 (CO), 155.5 (Ar), 157.8 (OCO), 171.8 (CO). Anal. Calcd for for $\mathrm{C}_{34} \mathrm{H}_{38} \mathrm{ClN}_{11} \mathrm{O}_{5} \cdot 3 \mathrm{HCl} \cdot 2 \mathrm{H}_{2} \mathrm{O}: \mathrm{C}, 47.40 ; \mathrm{H}$, 5.26; N, 17.88; Cl, 16.46. Found: C, 47.44; H, 5.20; N, $17.80 ; \mathrm{Cl}, 16.35$.

4-(6-(5-(4-Methylpiperazin-1-yl)-benzimidazol-2-yl)benzimidazol-2-yl)phenyl 2-(2-(3-(2-Chloroethyl)-3-nitrosoureido)-3-methylbutanamido)ethylcarbamate Trihydrochloride (5): Yield $=34 \%, \mathrm{mp}>300{ }^{\circ} \mathrm{C}$. ${ }^{1} \mathrm{H}-\mathrm{NMR}$ (DMSO$\left.d_{6}\right) \delta: 0.82\left(\mathrm{~d}, \mathrm{CH}_{3} J=6.7\right), 1.06\left(\mathrm{~d}, 3 \mathrm{H}, \mathrm{CH}_{3}, J=6.7 \mathrm{~Hz}\right)$, $2.65\left(\mathrm{~s}, 3 \mathrm{H}, \mathrm{N}-\mathrm{CH}_{3}\right), 2.35(\mathrm{~m}, 1 \mathrm{H}, \mathrm{CH}-), 2.80(\mathrm{~m}, 4 \mathrm{H}$, $\left.\mathrm{N}-\mathrm{CH}_{2}-\right), 3.24\left(\mathrm{t}, 2 \mathrm{H}, \mathrm{N}-\mathrm{CH}_{2}-, J=6.2 \mathrm{~Hz}\right), 3.38(\mathrm{~m}, 4 \mathrm{H}$, $\left.\mathrm{N}-\mathrm{CH}_{2}-\right), 3.46\left(\mathrm{t}, 2 \mathrm{H}, \mathrm{N}-\mathrm{CH}_{2}-, J=6.2 \mathrm{~Hz}\right), 3.55(\mathrm{t}, 2 \mathrm{H}$, $\left.-\mathrm{CH}_{2}-\mathrm{Cl}, J=6.2 \mathrm{~Hz}\right), 4.20\left(\mathrm{t}, 2 \mathrm{H}, \mathrm{N}-\mathrm{CH}_{2}-, J=6.2 \mathrm{~Hz}\right), 4.52$ (d, $\left.1 \mathrm{H}, \mathrm{CH}_{2}, J=7.9 \mathrm{~Hz}\right), 6.95$ (d, 1H, $\left.\mathrm{Ar}-\mathrm{H}, J=8.4 \mathrm{~Hz}\right), 7.05$ (s, 1H, Ar-H), 7.45 (d, 1H, Ar-H, J=9.0 Hz), 7.71 (d, $1 \mathrm{H}$, $\mathrm{Ar}-\mathrm{H}, J=9.2 \mathrm{~Hz}$ ), 7.82 (d, 2H, Ar-H, J=8.2 Hz), 8.04 (d, $1 \mathrm{H}, \mathrm{Ar}-\mathrm{H}, J=8.7 \mathrm{~Hz}$ ), 8.19 (d, $2 \mathrm{H}, \mathrm{Ar}-\mathrm{H}, J=9.4 \mathrm{~Hz}), 8.38$ $(\mathrm{s}, 1 \mathrm{H}, \mathrm{Ar}-\mathrm{H}) .{ }^{13} \mathrm{C}-\mathrm{NMR}$ (DMSO- $\left.d_{6}\right) \delta: 17.1\left(\mathrm{CH}_{3}\right), 31.5$ $(\mathrm{CH}), 38.4\left(\mathrm{CH}_{2}-\mathrm{NH}\right), 41.4\left(\mathrm{~N}-\mathrm{CH}_{3}\right), 42.0\left(\mathrm{CH}_{2}-\mathrm{Cl}\right), 41.3$ $\left(\mathrm{N}-\mathrm{CH}_{2}-\right), 43.6\left(\mathrm{~N}-\mathrm{CH}_{2}\right), 53.5\left(\mathrm{~N}-\mathrm{CH}_{2}-\right), 61.5\left(\mathrm{CH}_{2}-\mathrm{N}\right)$, 102.5 (Ar), 116.7 (Ar), 116.9 (Ar), 123.2 (Ar), 126.4 (Ar), 128.2 (Ar), 130.5 (Ar), 130.9 (Ar), 132.2 (Ar), 149.8 (Ar), 153.9 (Ar), 153.3 (CO), 155.5 (Ar), 157.8 (OCO), 171.5 (CO). Anal. Calcd for for $\mathrm{C}_{36} \mathrm{H}_{42} \mathrm{ClN}_{11} \mathrm{O}_{5} \cdot 3 \mathrm{HCl} \cdot 2 \mathrm{H}_{2} \mathrm{O}: \mathrm{C}$, 48.60; H, 5.55; N, 17.32; Cl, 15.94. Found: C, 48.54; H, $5.52 ; \mathrm{N}, 17.23 ; \mathrm{Cl}, 15.89$.

\section{PHARMACOLOGY}

Reagents and Materials Calf thymus DNA, homopolymers poly $(\mathrm{dA}-\mathrm{dT}) \cdot \operatorname{poly}(\mathrm{dA}-\mathrm{dT})$, and poly $(\mathrm{dG}-\mathrm{dC}) \cdot \operatorname{poly}(\mathrm{dG}-$ $\mathrm{dC})$, 3-(4,5-dimethylthiazol-2-yl)-2,5-diphenyltetrazolium bromide (MTT) were purchased from Sigma (U.S.A.). Supercoiled pKMp27 DNA, topoisomerase I and II were purchased from TopoGEN (U.S.A.). Stock cultures of breast cancer MCF-7 and MDA-MB-231 were purchased from the American Type Culture Collection, Rockville, MD. Dulbec- 
co's minimal essential medium (DMEM) and foetal bovine serum (FBS) used in cell culture were products of Gibco (U.S.A.). Glutamine, penicillin and streptomycin were obtained from Quality Biologicals Inc. (U.S.A.). $\left[{ }^{3} \mathrm{H}\right]$ Thymidine $(6.7 \mathrm{Ci} / \mathrm{mmol})$ was the product of NEN (U.S.A.).

Ultrafiltration Method A test compound $(100 \mu \mathrm{M})$ was mixed with calf thymus DNA $(0.5 \mathrm{~mm}$ as base pairs $)$ in $1.0 \mathrm{~TB}$ buffer ( $10 \mathrm{~mm}$ Tris $\cdot \mathrm{HC} 1(\mathrm{pH} 8)-1 \mathrm{~mm}$ EDTA containing $0.15 \mathrm{M} \mathrm{NaCl}$ ). The mixture was allowed to stand at room temperature overnight. The mixture was ultrafiltered using a ultrafree-MC centrifugal filter unit (PLCC NMWL 5000, Milipore) at $20^{\circ} \mathrm{C}$, then the content of the test compound in the filtrate was determined by UV-absorption measurement $\left(\mathrm{Abs}_{\mathrm{DNA}^{+}}\right)$and this value was taken as the concentration of free compound ([comp $\left.]_{\mathrm{DNA}+}\right)$. The same procedure was carried out with a solution of the test compound in the absence of DNA as the control (Abs. . $_{\text {DNA- }}$ and [comp $]_{\text {DNA- }}$, respectively). Measurements were made with a Unicam/Helios $\gamma$ amma UV-vis spectrophotometer at $\lambda_{\max }=341$ for compounds 3-5 and Hoechst 33258. Results are the means of three independent experiments. The DNA-binding ability of the test compound was defined by the following equation:

DNA binding ability (\%)

$=\left(1-[\mathrm{comp}]_{\mathrm{DNA}+} /[\mathrm{comp}]_{\mathrm{DNA}-}\right) \times 100=\left(1-\mathrm{Abs}_{\mathrm{DNA}+} / \mathrm{Abs}_{\mathrm{DNA}-}\right) \times 100$

Cell Culture Human breast cancer MDA-MB-231 and MCF-7 cells maintained in DMEM supplemented with $10 \%$ fetal bovine serum (FBS), $50 \mathrm{U} / \mathrm{ml}$ penicillin, $50 \mu \mathrm{g} / \mathrm{ml}$ streptomycin at $37^{\circ} \mathrm{C}$. Cells were cultured in Costar flasks and subconfluent cells were detached with $0.05 \%$ trypsin and $0.02 \%$ EDTA in calcium-free phosphate buffered saline, counted in hemocytometers and plated at $5 \times 10^{5}$ cells per well of 6-well plates (Nunc) in $2 \mathrm{ml}$ of growth medium (DMEM without phenol red with 10\% CPSR1). Cells reached about $80 \%$ of confluency at day 3 and in most cases such cells were used for the assays.

Cytotoxic Assay To examine the effect of studied drugs on MCF-7 and MDA-MB-231cells proliferation, the cells were seeded in 24 well tissue culture dishes at $1 \times 10^{5}$ cells/well with $1 \mathrm{ml}$ of growth medium. After $48 \mathrm{~h}$ $\left(1.8 \pm 0.1 \times 10^{5}\right.$ cells/well $)$ plates were incubated with varying concentrations of compounds $\mathbf{3}-\mathbf{5}$ and Hoechst 33258 and $0.5 \mu \mathrm{Ci}$ of $\left[{ }^{3} \mathrm{H}\right]$ thymidine for $24 \mathrm{~h}$ at $37^{\circ} \mathrm{C}$. Cells were rinsed 3 times with PBS, solubilized with $1 \mathrm{ml}$ of $0.1 \mathrm{~m}$ sodium hydroxide containing $1 \% \mathrm{SDS}$, scintillation fluid $(9 \mathrm{ml})$ was added and radioactivity incorporation into DNA was measured in scintillation counter.

Cell Viability Assay The assay was performed according to the method of Carmichael using 3-(4,5-di-methylthiazole-2-yl)-2,5-diphenyltetrazolium bromide (MTT). ${ }^{20)}$ Confluent cells, cultured for $48 \mathrm{~h}$ with various concentrations of the studied compounds in 6-well plates were washed three times with PBS and then incubated for $4 \mathrm{~h}$ in $1 \mathrm{ml}$ of MTT solution $(0.5 \mathrm{mg} / \mathrm{ml}$ of PBS $)$ at $37^{\circ} \mathrm{C}$ in $5 \% \mathrm{CO}_{2}$ in an incubator. The medium was removed and $1 \mathrm{ml}$ of $0.1 \mathrm{M} \mathrm{HCl}$ in absolute isopropanol was added to attached cells. Absorbance of converted dye in living cells was measured at a wavelength of $570 \mathrm{~nm}$. Cell viability of breast cancer cells cultured in the presence of ligands was calculated as a per cent of control cells.

Relaxation Assay of Topoisomerase I and II Super- coiled pKMp27 DNA $(0.5 \mathrm{mg})$ was incubated with 4 units of human topo I or II (TopoGEN), in relaxation buffer $(50 \mathrm{~mm}$ Tris (pH 7.8), $50 \mathrm{~mm} \mathrm{KCl,} 10 \mathrm{~mm} \mathrm{MgCl}_{2}, 1 \mathrm{~mm}$ DTT, $1 \mathrm{~mm}$ ethylene diaminetetraacetic acid (EDTA)), in the presence of varying concentrations of the test compounds. Reactions were carried out at $37^{\circ} \mathrm{C}$ for $1 \mathrm{~h}$ and then terminated by the addition of sodium dodecyl sulphate (SDS) to $0.25 \%$ and proteinase $\mathrm{K}$ to $250 \mathrm{mg} / \mathrm{ml}$. The reaction mixture was subjected to electrophoresis through a $0.8 \%$ agarose gel containing $0.5 \mathrm{mg} / \mathrm{ml}$ ethidium bromide in TBE buffer $(90 \mathrm{~mm}$ Trisborate and $2 \mathrm{~mm}$ EDTA). The gels were stained with ethidium bromide and photographed under UV light. For the quantitative determination of topoisomerase concentration activity, photographic negatives were scanned and the area representing supercoiled DNA, migrating as a single band at the bottom of the gel was measured using UVI-KS4000i gel documentation and analysis system (Syngen Biotech, U.S.A.). The concentrations of the inhibitor that prevented $50 \%$ of the supercoiled DNA from being converted into relaxed DNA ( $\mathrm{IC}_{50}$ values) were determined by averaging the data from at least three experiments.

Statistical Analysis In all experiments, the mean values for six independent experiments \pm standard deviations (S.D.) were calculated, unless otherwise indicated. The results were submitted to statistical analysis using Students $t$-test, accepting $p<0.05$, as significant.

\section{RESULTS AND DISCUSSION}

The synthetic pathway for the compounds described is illustrated in Fig. 1. The compound 1, as the starting material, was prepared following a published procedure by adding an excess of bromoethylisocyanate to Hoechst $33258 .{ }^{14)}$ A solution of bromide $\mathbf{1}$ in absolute ethanol was saturated at $0{ }^{\circ} \mathrm{C}$ with anhydrous ammonia and the mixture was stirred at room temperature for $48 \mathrm{~h}$ afforded the amine 2 in $78 \%$ yield. $N$-[N-(2-chloroethyl)- $N$-nitrosocarbamoyl $]$ amino acids were prepared by the general method described by Eisenbrand et al. ${ }^{18,19)}$ Finally, $N$-[N-(2-chloroethyl)- $N$-nitrosocarbamoyl $]-$ amino acids were conjugated with the amine $\mathbf{2}$ in the presence $N, N^{\prime}$-dicyclohexylcarbodiimide (DCC) in DMF gave the final compounds $\mathbf{3}-\mathbf{5}$ in moderate to good yields. These new chloroethylnitrosourea analogues of Hoechst 33258 (35) differ by the nature of amino acids side chains were isolated as the hydrochloride salts. The chemical structures of the synthesized compounds were confirmed by means their elemental analysis, ${ }^{1} \mathrm{H}$ - and ${ }^{13} \mathrm{C}-\mathrm{NMR}$.

Cell viability of breast cancer cells was measured by the method of Carmichael et al. using tetrazolium salt (Fig. 2). ${ }^{20)}$ Although growth inhibition was concentration-dependent in either cell line, it was more pronounced at shorter times, in MDA-MB-231 than MCF-7 (Fig. 2). In terms of reduction in cell viability, the compounds rank in both MCF-7 and MDAMB-231 cells in the order $\mathbf{3}>\mathbf{4}>\mathbf{5}>$ Hoechst 33258 . Among the derivatives, compound $\mathbf{5}$ in both MDA-MB-231 and MCF-7 proved to be only slightly more potent than Hoechst 33258 , with $\mathrm{IC}_{50}$ values of $63 \pm 2$ and $73 \pm 2 \mu \mathrm{M}$, respectively, compared to $92 \pm 2$ and $97 \pm 2 \mu \mathrm{M}$ for Hoechst 33258 . In contrast, compound 3, which contains the $N-[N-(2-$ chloroethyl)$N$-nitrosocarbamoyl]glicyne moiety is clearly much more active and showed a high level of cytotoxic potency, $\mathrm{IC}_{50} 5 \pm 2$ 

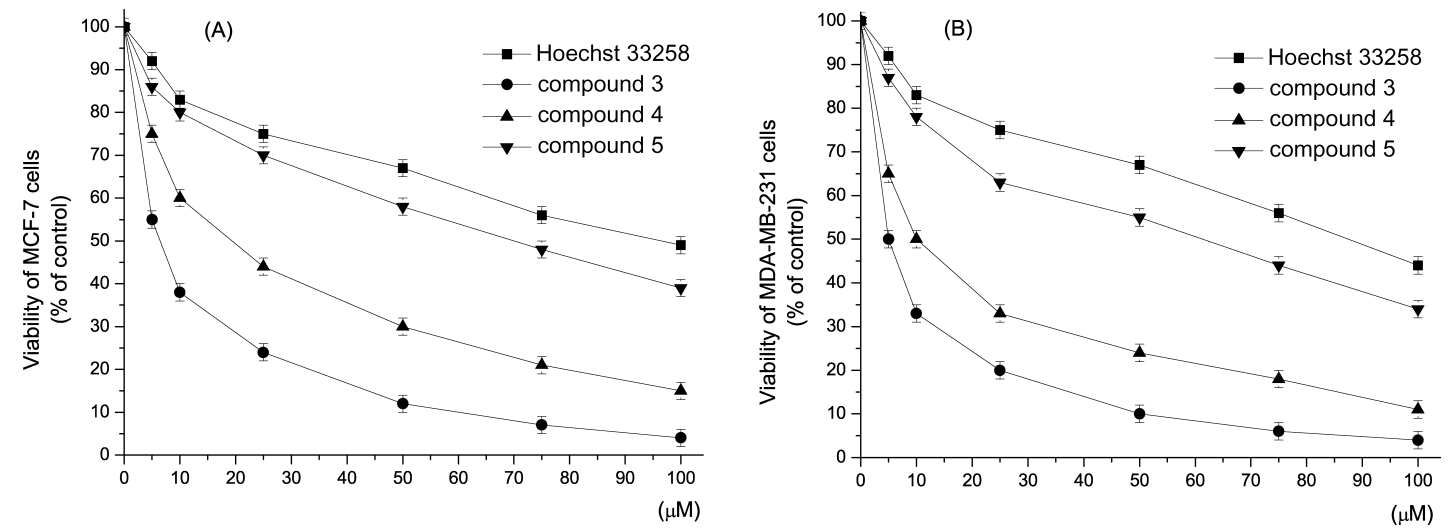

Fig. 2. Viability of MCF-7 (A) and MDA-MB-231 (B) Cells Treated for $48 \mathrm{~h}$ with Different Concentrations of Compounds 3 - 5 and Hoechst 33258 Mean values \pm S.D. from three independent experiments done in duplicate are presented.
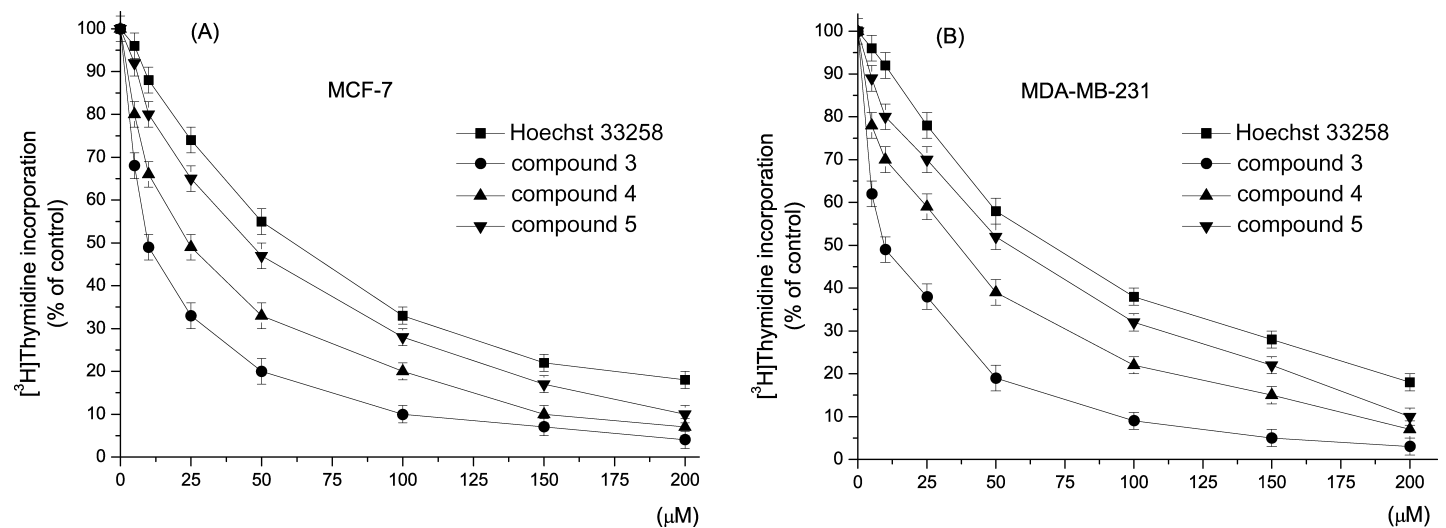

Fig. 3. Cytotoxic Effects of Hoechst 33258 and Compounds $\mathbf{3}-\mathbf{5}$ on the Cultured Breast Cancer MCF-7 (A) and MDA-MB-231 (B) Cells as Measured by Inhibition of $\left[{ }^{3} \mathrm{H}\right]$ Thymidine Incorporation into DNA

Mean values \pm S.D. of 3 independent experiments $(n=4)$ done in duplicates are presented.

and $8 \pm 2 \mu \mathrm{M}$ in MCF-7 and MDA-MB-231, respectively. Compound $\mathbf{3}$, the most active of the series, is approximately 20 times more potent than Hoechst 33258.

To analyze if the inhibition in cell viability was due to decreased cell proliferation, we measured DNA synthesis in presence of compounds $\mathbf{3} \mathbf{- 5}$ and Hoechst 33258 (Fig. 3). Measurement of $\left[{ }^{3} \mathrm{H}\right]$ thymidine incorporation during DNA synthesis by proliferating breast cancer cells showed that these compounds inhibited DNA synthesis in a dose-dependent manner. Furthermore, the profiles of DNA synthesis obtained were similar between MCF-7 and MDA-MB-231 (Fig. $3)$. The concentrations of $\mathbf{3}, \mathbf{4}, \mathbf{5}$ needed to inhibit $\left[{ }^{3} \mathrm{H}\right]$ thymidine incorporation into DNA by $50 \%\left(\mathrm{IC}_{50}\right)$ in MDA-MB231 was found to be $8 \pm 2 \mu \mathrm{M}, 38 \pm 3 \mu \mathrm{M}$ and $60 \pm 2 \mu \mathrm{M}$, respectively, suggesting higher cytotoxic potency compared to Hoechst $33258\left(\mathrm{IC}_{50}=68 \pm 2 \mu \mathrm{M}\right)$. The concentrations of 3, 4, 5 and Hoechst 33258 needed to $50 \%$ reduction in $\left[{ }^{3} \mathrm{H}\right]$ thymidine incorporation into DNA in breast cancer MCF-7 ( $\left.\mathrm{IC}_{50}\right)$ was found to be $8 \pm 2 \mu \mathrm{M}, 37 \pm 2 \mu \mathrm{M}, 49 \pm 2 \mu \mathrm{M}$, and $55 \pm 2 \mu \mathrm{M}$, respectively. Because the antiproliferative effect of compounds $\mathbf{3}-\mathbf{5}$ is independent of the estrogen receptor status of the breast cancer cells, these potent inhibitors are a potential pharmacological agents for the treatment of both hormone responsive and nonresponsive breast cancer cells.

To test whether cytotoxic properties were related to DNAbinding the compounds $\mathbf{3}-\mathbf{5}$ were evaluated in a cell-free system. The binding affinity for a given DNA sequence is determined by a number of factors, including hydrogen bonding, electrostatic interactions and ligand conformation. ${ }^{5,10)}$ Hoechst 33258 is known to form hydrogen bonds along the minor groove of DNA through the benzimidazole moiety, both by hydrogen acceptor and donor. The presence of the guanine $\mathrm{NH}_{2}$ sterically impedes the drug from binding across GC pairs, although footprinting studies indicate that a GC base pair is generally present at the end of the binding site. $^{9,10)}$ The DNA-binding ability of compounds $\mathbf{3}-\mathbf{5}$ was evaluated by the ultrafiltration method (Table 1). ${ }^{14-17)}$ The binding constants $K_{\mathrm{a}}$ and number of sites per nucleotide $n$ were estimated from Scatchard plots using the classical Scatchard equation for independent binding sites without cooperativity. $^{21)}$ The order of DNA-binding under the utrafiltration assay conditions of the test compounds is $\mathbf{3}>\mathbf{4}>\mathbf{5}>$ Hoechst 33258. As can be seen from the Table 1, the binding constant $\left(K_{\mathrm{a}}\right)$ for compounds $\mathbf{3}$-5 varies from $9.9 \cdot 10^{3} \mathrm{M}^{-1}$ for compound 3 to $7.2 \cdot 10^{3} \mathrm{M}^{-1}$ for Hoechst 33258 . The flexible nature of $-\mathrm{NH}-\left(\mathrm{CH}_{2}\right)_{2} \mathrm{NH},-$ group permits the compounds $3-5$ to assume an optimum conformation, thus binding effectively to double-stranded DNA. Therefore, in the case of compounds $\mathbf{3}-\mathbf{5}$ the DNA-binding increases to compare Hoechst 33258. Since calf thymus DNA is heterogeneous in base sequence and about $42 \%$ GC, the DNA-binding ability with calf thymus DNA characterizes the strength 
Table 1. DNA-Binding Abilities of Compounds $\mathbf{3}-\mathbf{5}$ and Hoechst 33258 Determined by Ultrafiltration Assay Using Calf Thymus DNA

\begin{tabular}{|c|c|c|c|c|c|c|}
\hline \multirow[b]{2}{*}{ Comp. } & \multirow[b]{2}{*}{$\begin{array}{c}\text { Abs. } \\
\operatorname{DNA}(-)^{a)}\end{array}$} & \multirow[b]{2}{*}{$\begin{array}{l}\text { Abs. DNA } \\
\left.\text { DNA }(+)^{a}\right)\end{array}$} & \multirow[b]{2}{*}{$\begin{array}{c}\text { DNA- } \\
\text { binding } \\
(\%)\end{array}$} & \multicolumn{3}{|c|}{ Scatchard analyses } \\
\hline & & & & $\begin{array}{c}\text { Scatchard } \\
\left(K_{\mathrm{a}}\right) \\
\left(10^{3} \mathrm{M}^{-1}\right)\end{array}$ & $\begin{array}{l}\text { Binding } \\
\text { sites }(n) \\
\text { (per bp) }\end{array}$ & $\begin{array}{c}\text { Correlation } \\
\text { coefficient } \\
(R)\end{array}$ \\
\hline $\begin{array}{c}\text { Hoechst } \\
33258\end{array}$ & 0.469 & 0.143 & 69.5 & 7.2 & 0.4 & 0.76 \\
\hline 3 & 0.476 & 0.100 & 79.0 & 9.9 & 0.7 & 0.74 \\
\hline 4 & 0.476 & 0.111 & 76.7 & 8.6 & 0.7 & 0.75 \\
\hline 5 & 0.476 & 0.120 & 74.8 & 7.6 & 0.7 & 0.73 \\
\hline
\end{tabular}

a) The UV-absorption was measured at $\lambda_{\max }=341 \mathrm{~nm}$ after 5 dilution with 1.0 buffer. b) DNA binding ability $(\%)=\left(1-\mathrm{Abs}_{\mathrm{DNA}^{+}} / \mathrm{Abs}_{\mathrm{DNA}-}\right) \times 100$.

of the interaction with heterogeneous base sequences. The homopolymer DNA-binding data reported in Table 2 characterizes the affinity of the compounds $\mathbf{3}-\mathbf{5}$ for a more limited set of DNA-binding sites and can give an indication of basesequence specificity for DNA-binding molecules. These compounds as well as Hoechst 33258 well interact with AT base pair compared with GC pair. These data shows that in broad terms the cytotoxic potency of $\mathbf{3}-\mathbf{5}$ in cultured breast cancer MCF-7 and MDA-MB-231 cells increases in accord with their increases in DNA affinity, as shown by the binding constant values (Table 1). This activity may be related to the ability of these compounds to inhibit transcription, especially at AT-rich sequences.

Many DNA-binding agents exert their antitumour effect, at least in part, by inhibition of topo I (e.g. camptothecin) or topo II (e.g. doxorubicin). ${ }^{22,23)}$ DNA topoisomerases are nuclear enzymes capable of resolving the topology of DNA to allow its replication. ${ }^{22-24)}$ Hence, we examined the new compounds for their ability to interfere with the activity of these enzymes. The effect of the compounds $\mathbf{3}-\mathbf{5}$ and Hoechst 33258 on the catalytic activities of purified human topo I and II was quantified by measuring the action on supercoiled plasmid DNA substrate as a function of increasing concentration of the ligands by the use of agarose gel electrophoresis. The concentrations of the inhibitor that prevented $50 \%$ of the supercoiled DNA from being converted into relaxed DNA ( $\mathrm{IC}_{50}$ values) were determined (Table 2 ). These results demonstrated that $\mathbf{3}-\mathbf{5}$ had topo I inhibitory activity at concentration of $2-15 \mu \mathrm{M}$. They also inhibited topo II activity at the same concentration range (Table 2). The compound 3 was the most potent topoisomerase I and II inhibitor, with $50 \%$ inhibitory concentration ( $\left.\mathrm{IC}_{50}\right) 2 \mu \mathrm{M}$, which is better than of Hoechst 33258. The topoisomerase-targeting drugs can be classifed as either topo poisons, which act by stabilizing enzyme-DNA cleavable complexes leading to DNA breaks, or topo catalytic inhibitors, which act at stages in the catalytic cycle of the enzyme where both DNA strands remain intact and no DNA strand breaks occur. ${ }^{22-24)}$ It is likely that the ability of compounds $\mathbf{3}-\mathbf{5}$ to inhibit the activity of topo I and II that we have observed (Table 2) is simply due to blockade of the binding of these enzymes to DNA.

In conclusion, these studies present a series of bis-benzimidazole compounds with a novel structural motif that still retains the properties of high DNA affinity and significant specificity for AT rich nucleic acid homopolymers. The compounds $3-5$ have both a higher sequence recognition capac-
Table 2. Base Pair Specificity of Compounds $\mathbf{3}-\mathbf{5}$ and Hoechst 33258 Determined by Utrafiltration Assay

\begin{tabular}{ccccc}
\hline \hline \multirow{2}{*}{ Compounds } & \multicolumn{2}{c}{$\begin{array}{c}\text { DNA-binding ability } \\
(\%)^{a)}\end{array}$} & $\begin{array}{c}\text { Inhibition } \\
\text { of Topo I } \\
(\mu \mathrm{M})^{b)}\end{array}$ & $\begin{array}{c}\text { Inhibition } \\
\text { of Topo II } \\
(\mu \mathrm{M})^{b)}\end{array}$ \\
\cline { 2 - 3 } & AT & GC & & \\
\hline Hoechst 33258 & 81.4 & 41.5 & 30 & 35 \\
$\mathbf{3}$ & 88.4 & 42.4 & 2 & 2 \\
$\mathbf{4}$ & 83.9 & 41.5 & 5 & 10 \\
$\mathbf{5}$ & 81.6 & 43.6 & 15 & 15 \\
\hline
\end{tabular}

a) DNA-binding ability of Hoechst 33258 and compounds $\mathbf{3}-\mathbf{5}$ was determined by ultrafiltration assay. AT refers to poly $(\mathrm{dA}-\mathrm{dT})_{2}$ and $\mathrm{GC}$ to poly $(\mathrm{dG}-\mathrm{dC})_{2} . \quad b$ ) The concentrations of the inhibitor that prevented $50 \%$ of the supercoiled DNA from being converted into relaxed $\mathrm{DNA}\left(\mathrm{IC}_{50}\right.$ values) were determined by averaging the data from at least three experiments.

ity and inhibitory topoisomerase potency than Hoechst 33258. It is probable that deregulation of DNA replication and transcription by inhibition of topoisomerase activity contribute significantly to the cytotoxicity of compounds $\mathbf{3}-\mathbf{5}$ in addition to primary drug-DNA reaction products. ${ }^{22,25)}$ There is qualitative agreement between cytotoxic potency and DNA affinity for compounds $\mathbf{3}-\mathbf{5}$.

It should be noted that other factors such as low penetration into cell, cellular distribution and metabolic deactivation may also influence the cytoxicity results, but they are not assessed in the present study. Further biological evaluation is underway and these results, cell uptake studies and interaction of these compounds with nucleosomal DNA fragments which contain isolated ligand binding sites will be described in due course.

\section{REFERENCES}

1) Schabel F. M., Jr., Cancer Res., 23, 725-731 (1963).

2) Tong W. P., Kirk M. C., Ludlum D. B., Cancer Res., 42, 3102-3105 (1982).

3) Hartley J. A., Gibson N. W., Kohn K. W., Mattes W. B., Cancer Res., 46, 1943-1947 (1986).

4) Reddy B. S. P., Sharma S. K., Lown J. W., Curr. Med. Chem., 8, 475508 (2001).

5) Neidle S., Nat. Prod. Rep., 18, 291-309 (2001).

6) Denny W. A., Curr. Med. Chem., 8, 533-544 (2001).

7) Bartulewicz D., Bielawski K., Bielawska A., Różański A., Eur. J. Med. Chem., 36, 461-467 (2001).

8) Cozzi P., Farmaco, 58, 213-220 (2003).

9) Spink N., Brown D. G., Skelly J. V., Neidle S., Nucleic Acids Res., 22, 1607-1612 (1994).

10) Neidle S., Biopolymers, 44, 105-121 (1997).

11) Mann J., Baron A., Opoku-Boahen Y., Johansson E., Parkinson G., Kelland L. R., Neidle S. A., J. Med. Chem., 44, 138-144 (2001).

12) Soderlind K. J., Gorodetsky B., Singh A. K., Bachur N. R., Miller G. G., Lown J. W., Anti-Cancer Des., 14, 19-36 (1999).

13) Gravatt G. L., Baguley B. C., Wilson W. R., Denny W. A., J. Med Chem., 37, 4338-4345 (1994).

14) Bielawski K., Bielawska A., Wołczyński S., Biol. Pharm. Bull., 25 916-919 (2002).

15) Shichita M., Shimazawa R., Nakajima O., Mizoguchi H., Hashimoto Y., Iwasaki S., Biol. Pharm. Bull., 18, 637-639 (1995).

16) Fukutomi R., Kagechika H., Hashimoto Y., Shudo K., Chem. Pharm. Bull., 44, 1983-1985 (1996).

17) Bielawski K., Wołczyński S., Bielawska A., Biol. Pharm. Bull., 24, 704-706 (2001)

18) Tang W., Eisenbrand G., Arch. Pharm. (Weinheim), 314, 910-917 (1981).

19) Ehresmann K., Zelezny O., Eisenbrand G., Arch. Pharm. (Weinheim), 317, 481-487 (1984). 
20) Carmichael J., Degraff W., Gazdar A., Minna J., Mitchell J., Cancer Res., 47, 936-942 (1987).

21) Scatchard G., Ann. N.Y. Acad. Sci., 51, 660-672 (1949).

22) Chen A. Y., Liu L. F., Annu. Rev. Pharmacol. Toxicol., 34, 191-218 (1994).
23) Fortune J. M., Osheroff N., Prog. Nucleic Res. Mol. Biol., 64, 221253 (2000).

24) Champoux J. J., Annu. Rev. Biochem., 70, 369-413 (2001).

25) Ali-Osman F., Berger M. S., Rajagopal S., Spence A., Livingston R. B., Cancer Res., 53, 5663-5668 (1993). 